\title{
Interest Rate Pass-Through and Monetary Transmission in Asia
}

\author{
Pih Nee Tai \\ School of Mathematical Sciences, Universiti Sains Malaysia \\ 11800 Pulau Pinang, Malaysia \\ Tel: 60-4-653-5285Ｅ-mail: pannytai86@gmail.com
}

Siok Kun Sek (Corresponding author)

School of Mathematical Sciences, Universiti Sains Malaysia

11800 Pulau Pinang, Malaysia

Tel: 60-4-653-5285 E-mail: sksek@usm.my

Wai Mun Har

Faculty of Accountancy and Management Universiti Tunku Abdul Rahman

Bandar Sungai Long, 43000 Selangor, Malaysia

Tel: 60-3- 9019-4722Ｅ-mail: harwm@mail.utar.edu.my

Received: October27, $2011 \quad$ Accepted: November 24, $2011 \quad$ Published: February 1, 2012
doi:10.5539/ijef.v4n2p163
URL: http://dx.doi.org/10.5539/ijef.v4n2p163

The research is financed by Short Term Grant, Universiti Sains Malaysia.

\begin{abstract}
This study seeks to examine the effectiveness of interest rates transmission mechanism from money market rate into retail banking rate in several Asian countries. In particular, we intend to investigate the differences in the degree of pass-through from monetary policy rate into deposit and lending rates across countries and between the pre- and post-crisis of 1997. The study is carried out by running the Seemingly Unrelated Regression (SUR) equations. The results suggest that the transmission rate from money market rate into deposit and lending rates is slow and sluggish across economies. There is no much difference between the pass-through rate into deposit and lending rates but the pass-through into deposit rate is slightly higher than that in lending rate. Most of the countries have slower adjustment rates after the crisis 1997, indicating low effectiveness of monetary policy, imperfect financial market and lower degree of financial integration if these economies. However, there is an exception for Malaysia.
\end{abstract}

Keywords: Interest rate pass- through, Monetary policy, Transmission rate, Financial integration

\section{Introduction}

The outbreak of financial crisis during year 1997 has attracted a substantial amount of attention from economical researchers. Many of them are interested to investigate the impact of crisis on the economic structures and monetary policy mechanism. One way to evaluate the performance of monetary policy is through the study on the interest rate pass-through. High interest rate pass-through implies the close link between monetary policy rate and the retail banking rate. High speed of long run policy transmission indicates effective interest rate channel. Higher pass-through rate implies more effective monetary policy, higher market perfect competition and higher degree of financial integration. If the government effectively controls the market rate, then the economy will achieve the policy target. An incomplete interest rate pass-through can lead to the failure of monetary policy to stabilize shocks.

The principal aim of this study is to explore the effectiveness of interest rate transmission mechanism from money market rate or policy rate into retail banking rate in Asian countries. In particular, we compare the pass-through rate across Asian countries and between the two sub-periods of pre- and post-crisis. We focus the study on several Asian countries that have experienced the financial crisis of 1997. The period of study is from 1988 until 2010. The data is divided into two sub-periods, i.e. pre-crisis (January 1988 - June 1997) and post-crisis (January 1999 - December 
2010). Applying the Seemingly Unrelated Regression (SUR) approach, we show that most of the Asian countries experience slower adjustment rate after the financial outbreak in 1997, except Malaysia. High degree of interest rate stickiness or failure of government in controlling the market rate is the possible factors for the slow and small transmission rate into deposit and lending rates.

The remaining sections are organized as follows: Section 2 discusses the research background; Section 3 explains the pass-through equations; Section 4 is about data and methodology; Section 5 summarizes the findings and the last section concludes.

\section{Research Background}

Interest rate pass-through is defined as the degree and the speed of changes of policy or market rate into retail banking rate (ur Rehman, 2009). In other words, interest rate pass-through is a process where the official interest rate is transmitted to other interest rates. The central bank of a country will increase the official interest rate when the rate of inflation beyond the target band. The success of the monetary policy in stabilizing inflation and achieving inflation targets depends on the stickiness of market interest rates. An incomplete interest rate pass-through can lead to the violation of the Taylor principle and failure of monetary policy to stabilize shocks (Marotta, 2009). The nature of interest rate pass-through will determine the degree of competitiveness and the soundness of the financial system (Aydin, 2007 and Hofmann, 2002). A quicker, symmetric and complete interest rate pass-through will lead to a well functioning, competitive and efficient financial system.

The interest rate can be split into two stages. The first stage investigates the pass-through of monetary policy rate into the short term and long term market rates. The stability of the yield curve highly affects the first stage. If the yield curve remains constant over time, then the market rates is said to be proportionate. Nonetheless, any changes in the yield curve may alter the size of pass-through. The second stage investigates how changes in the market rates affect bank deposit and lending rates (ur Rehman, 2009). For the second stage of interest rate pass-through, the relationship between market rates, bank deposit and lending rates of comparable maturity can be investigated with the cost of funds approach (de Bondt, 2005).

Most of the researches seek to investigate the degree and speed of adjustment of banking rates to changes in money market rates. Previous studies report that changes of retail rate into market interest rate are incomplete. These studies also find that the degree and the speed of pass-through vary across countries, especially retail rates. Besides, the rates are very different across countries, which may due to the macroeconomics or other factors. Among these studies include Borio \& Fritz (1995), Cottarelli \& Kourelis (1994), Mozzami (1999), Mojon (2000), Kleimeier and Sander (2000), Donnay and Degryse (2001), Toolsema et al. (2002), Espinosa-Vega and Rebucci (2003) and de Bondt (2002).

Many studies reveal that interest rate pass-through is sluggish in the short run. According to Weth (2002), the pass-through has the tendency to remain sluggish in the short term but it cannot remain incomplete in the long term. One of the reasons of previous statement: adjustment or menu costs can impact banks to react sluggishly towards changes in the market rates. Besides, the maturity mismatches of banks' loan and deposit portfolio impacts on how they adjust their lending rates. Thus, the banks will have less pressure when more long term loans are covered by long term deposits, if their liabilities have less sensitivity towards market rates. Four theories are identified to explain the stickiness in interest rate: agency costs (Stiglitz and Weiss, 1981), adjustment costs (Cottarelli and Kourelis, 1994), switching costs (Klemperer, 1987), and risk sharing (Fried and Howitt, 1980).

Some studies report different results, i.e. interest rate pass-through tends to be full in the short run. For example, Crespo-Cuaresma et al. (2004) apply the Autoregressive Distributed Lag (ARDL) model to estimate the pass-through from policy rates to lending rates. It is found that the transmission tends to be full in the short run. Deposit rate pass-through tends to be sticky in both short and long run. Besides, there is no asymmetric behaviour on the speed of pass-through, depending on whether policy interest rate increases or decreases.

There are few factors that cause differences in strength and speed of monetary interest rate transmission. They are the differences in the structural properties financial systems, disintermediation, intensity of competition in the banking sector, capitalization and liquidity position of banks, monetary policy and interest rate volatility (Horvath et al., 2004), interest rate elasticity of the demand for retail bank products, asymmetric or switching costs of the retail bank market (de Bondt, 2005), size of changes in money market rate, distance of bank rates from their long term equilibrium level and lastly the sign of yield shocks (Horvath et al., 2004).

\section{Interest Rate Pass- Through Equations}

There are two approaches to estimate the interest-rate pass-through, i.e. the cost of funds approach and the monetary policy approach, see Grynkiv, (2007)). We apply the monetary policy approach. This approach controls the availability of connection between policy interest rate and bank retail interest rates. 
The relationship between money market and retail rates (lending and deposit rates) can be explained using the marginal cost pricing model by de Bondt (2002). Applying the concept of perfect market competition where with complete information where prices equal marginal costs, the derivative of prices with respect to marginal costs equals one but becomes less than one if the perfect competition and information prices are relaxed (Rousseas, 1985). Using this concept to the price setting of banks, marginal cost pricing model equation can be written as:

$$
b r=\gamma_{0}+\gamma_{1} m r
$$

where $b r$ is the bank interest rate (lending or deposit rate), $\gamma_{0}$ is a constant markup and $m r$ is the marginal cost price which is proxied by the money market rate. The money market rate is the most suitable marginal cost prices due to its accuracy on the reflection of the marginal funding costs. Parameter $\gamma_{1}$ is the coefficient of pass-through rate. When $\gamma_{1}$ is unity, the pass-through from money market rate to retail interest rate is full or complete. On the other hand, if $0<\gamma_{1}<1$, the pass-through rate is incomplete. The incomplete rate implies that the demand elasticity of deposits and loans is incomplete and also the banks have some degrees of market power. Factors that affect market power include the existence of switching costs, asymmetric information costs, and also the preconditions for a degree of monopoly power and administrated pricing (Niggle, 1987).

In this study, we seek to estimate the pass-through of policy rate into two types of retail bank rates, which are the lending and deposit rates. The transmission of policy rate into the lending and deposit rates are examined in two conditions: long run and short run pass-through rates. Previous studies use different specifications in constructing interest rate pass-through equations. For example, using different lag length and data of interest rate. The common specifications of pass-through equations can be written as:

$$
\begin{gathered}
\Delta d r_{1 t}=c_{1}+\sum_{k=0}^{m} c_{2, k} \Delta m m r_{1 t-k}+\sum_{k=0}^{m} c_{3, k} \Delta d r_{1 t-1-k}+\varepsilon_{1 t} \\
\Delta l r_{2 t}=c_{4}+\sum_{k=0}^{m} c_{5, k} \Delta m m r_{2 t-k}+\sum_{k=0}^{m} c_{6, k} \Delta l r_{2 t-1-k}+\varepsilon_{2 t}
\end{gathered}
$$

where $d r$ indicates the deposit rate, $l r$ is the lending rate, $m m r$ indicates money market rate, $k=0,1, \cdots m$ is the lag length, $t$ is the time, $c$ and $c_{i k}$ where $i=1,2, \cdots, n$ are the coefficients.

If a variable is not stationary at level, then it has to undergo the first differencing process. $\Delta$ denotes the first differencing operator. The degrees of short-run pass-through from money market rate into deposit and lending rate are $\sum_{k=0}^{m} c_{2, k}$ and $\sum_{k=0}^{m} c_{5, k}$ respectively. The degrees of long-run pass-through from money market rate into deposit and lending rates are

$$
\sum_{k=0}^{m} c_{2, k} / 1-\sum_{k=0}^{m} c_{3, k} \text { and } \sum_{k=0}^{m} c_{5, k} / 1-\sum_{k=0}^{m} c_{6, k} \text { respectively. }
$$

\section{Data and Methodology}

\subsection{Data}

The main objective of this study is to compare the interest rate pass-through between the pre- and post- Asian financial crisis of 1997. The pass-through of money market rate into deposit and lending rates of each country is investigated in two sub-periods which are the pre- and post-crisis periods. For the pre-crisis period, the data are from January 1988 until June 1997; while for the post-crisis period, the data are from January 1999 until December 2010. The data include deposit rate (DR), lending rate (LR) and money market rate (MMR). The data are obtained from International Financial Statistics (IFS). Table 1 summarizes the data used in this study.

We focus the analysis in six Asian economies namely Hong Kong, Indonesia, Korea, Malaysia, Philippines, Singapore and Thailand. The financial crisis of 1997-98 had large negative impacts in some economies such as Thailand and Indonesia while Hong Kong, Korea and Singapore did not receive large impact from the crisis. By plotting the interest rate and CPI (see Figure 1-4 in appendix), we observe that interest rates and CPI in Indonesia and Philippines are more fluctuate compare to the other economies. These two economies are also very affected by the financial crisis. The interest rates and CPI of Indonesia exhibit a big jump during the crisis period of 1997-98. Besides, we also observe that both interest rates and CPI show very similar trend. Therefore, in order to get a clear 
impact of financial crisis on the dynamic of interest rate pass-through, we divide the data into pre- and post-crisis periods.

\subsection{Seemingly Unrelated Regression (SUR) Approach}

SUR is one of the approaches of Generalized Least Squares (GLS). GLS is applied in linear regression model where it can estimate the unknown parameters. When there is a heteroskedasticity problem, that is the observations share different variances, then the GLS method is used. The general linear equation for SUR is shown in the following and it can be simplified as $Y_{i t}=X_{i t} \beta_{i}^{\prime}+u_{i t}$ :

$$
\begin{array}{r}
y_{1 t}=x_{1 t} \beta_{1}^{\prime}+u_{1 t} \\
y_{N t}=x_{N t} \beta_{N}{ }^{\prime}+u_{N t}
\end{array}
$$

where $y_{i t}$ is a dependant variable, $x_{i t}=\left(1, x_{i t, 1}, x_{i t, 2}, \ldots, x_{i t, K_{i-1}}\right)$ is a $K_{i}$ - vector of explanatory variables for observable unit $i, u_{i t}$ is an unobservable error term, it represents $i$-th equation in the system and $t$-th observation (Moon and Perron, 2006). $i$ indicates regression equation number and $i=1, \cdots, N, t=1, \cdots, T$ is the observation index, $\beta_{i}^{\prime}$ is the transpose of a vector of unknown regression coefficients which need to be estimated .

$$
\begin{aligned}
& Y_{i t}=\left[\begin{array}{lll}
\Delta d r & \Delta l r & \Delta m m r
\end{array}\right] \\
& X_{1 t}=\left[1, \Delta m m r_{1 t}, \cdots, \Delta m m r_{1 t-m}, \Delta d r_{1 t}, \cdots, \Delta d r_{1 t-m}\right] \\
& X_{2 t}=\left[1, \Delta m m r_{2 t}, \cdots, \Delta m m r_{2 t-m}, \Delta l r_{2 t}, \cdots, \Delta l r_{2 t-m}\right] \\
& \beta_{1}=\left[\begin{array}{lllllll}
c_{1} & c_{2,0} & \cdots & c_{2, m} & c_{3,0} & \cdots & c_{3, m}
\end{array}\right]^{\prime} \\
& \beta_{2}=\left[\begin{array}{llllllll}
c_{4} & c_{5,0} & \cdots & c_{5, m} & c_{6,0} & \cdots & c_{6, m}
\end{array}\right]^{\prime}
\end{aligned}
$$

The pass-through equations are estimated using lag length up to 3 . The results applying different lag lengths are quite similar. In order to save space, we only summarize the result of lag one.

\section{Estimations Results}

\subsection{Diagnostic Tests}

The analysis involves three main issues. First, we need to investigate the stationarity of the variables. Second, we have to decide the estimation approach. In this study, we need to determine between Ordinary Least Squares (OLS) and Generalized Least Square (GLS). Lagrange Multiplier (LM) test is used here to assist us in identifying the approach we should choose. Third, after choosing the appropriate approach, we have to proceed with estimation.

In this study, Augmented Dickey-Fuller (ADF) method is applied to check the stationarity of three types of interest rates which are the lending, deposit and money market rates in the early stage. The rejection of the null hypothesis indicates that the series is stationary. On the other hand, the failure to reject the null hypothesis of unit-root implies that the series is not stationary and the series needs to transform into stationary form through first differencing process.

After transforming the data into stationary form, we have to decide the estimation approach that is whether to use GLS or OLS. LM test is applied in this study where $\lambda_{L M}=T \sum_{i=2}^{M} \sum_{j=1}^{i-1} r_{i j}^{2}$ where $r_{i j}=\hat{s}_{i j} /\left(\hat{s}_{i i} \hat{s}_{j j}\right)^{\frac{1}{2}}$ is obtained from the OLS residuals and the correlation coefficient is chi-square distributed. It tests the diagonality of covariance matrix, $\Sigma$. The diagonal elements of a covariance matrix are the variances of the matrix. $\lambda_{L M}$ is asymptotically distributed as chi-square.

If the computed $\lambda_{L M}>\chi^{2}$ that is the heteroskedasticity exists, then the test suggests the use of Generalized Least Square (GLS) instead of Ordinary Least Square (OLS) (Sek, 2010). Homoskedasticity indicates that all variances of the error term are constant (White, 1980). However, if the $\lambda_{L M}<\chi^{2}$ that is the homoskedasticity present, then OLS can be used.

Table 2 and 3 summarize the results of ADF unit-root test for the pre- and post-crisis periods. The results show that in most cases, DR and LR are not stationary in level and need to be differenced to become stationary. However, 
MMR is stationary in level in some countries. Table 4 summarizes the results of LM test for the two sub-periods. The results indicate that one should adopt GLS rather than OLS. Therefore, the interest-rate pass-through equations are estimated using SUR.

\subsection{Results of Interest Rate Pass-Through}

The results of SUR are summarized in Table 5 and 6. Comparison of results can be made from three aspects, i.e. results between the two sub-periods of pre- and post-crisis, results between lending and deposit rates and results of short-run versus long-run rates.

Comparing the results between pre- and post-crisis periods, it is observed that in general both lending and deposit rates (either short-run or long-run rate) in the pre-crisis period are higher than that in the post-crisis period. To be specified, the deposit rates in all cases in the pre-crisis period are larger than the rates of post-crisis period except in Malaysia. For lending rate, the same condition holds with the exception of Malaysia, Korea and Singapore. In Korea, the lending rate in the pre-crisis is very small (i.e. in negative value) which indicate a very weak influence of monetary policy rate on retail banking rate. In Malaysia, both deposit and lending rates in the post-crisis period increase substantially relative to the rates of pre-crisis. The result implies the improvement in the monetary policy of Malaysia from weak to the influential one.

Next, comparing the results of deposit and lending rates, we observe that in general the deposit rate is higher than the lending rate although the difference is not large. However, the large exception is observed in Philippines where the lending rate in the pre-crisis period is double higher than the deposit rate. In general, the results indicate that deposit rate is more influenced by the change in the monetary policy rate relative.

Comparing the results of pass-through from money market rate into deposit and lending rates between short-run and long-run terms, we observe that the results vary across economies. In most cases, the pass-through rate (both lending and deposit rates in the pre- and post-crisis periods) do not exhibit large differences from short-run to long-run except in Malaysia and China (Hong Kong). In Malaysia, the deposit rate in the pre-crisis period increases from short-run to the long-run path but after the crisis, the deposit rate declines from short-run to long-run path. In China (Hong Kong), both deposit and lending rates increase apparently (for both sub-periods) in the long-run relative to that in the short-run.

Comparing the pass-through rates across economies, the results show that Thailand and Korea have very low pass-through into deposit and lending rates. On the other hand, Malaysia and China (Hong Kong) exhibit relatively very high pass-through rates. The results reveal several possibilities. The low pass-through in retail banking rates could imply that the monetary policies in these economies are very weak in influencing the retail banking rates. The monetary policy in these economies cannot effectively control the economic transmissions and the financial market integration is weak in these economies. In contrast, the monetary policy in Malaysia and China (Hong Kong) has gained its effectiveness aftermath the crisis. Another possible explanation is the low pass-through can be due to the stickiness in interest rate. The retail banking rates are slowly adjusted due to the cost of adjustment.

\section{Main Findings and Conclusion}

In general, past-through rate into lending and deposit rates does not show large difference. In most cases, the pass-through rate into lending rate is slightly smaller compared to the deposit rate. The interest rate pass-through into lending and deposit rates is very slow and small, except Malaysia, Hong Kong and Singapore.

Interest rate pass-through into lending and deposit rates varies across economies and over. Interest rate pass-through into deposit rate has declined in all economies except Malaysia. Similarly, the pass-through rate into lending rate also declines in majority economies except the case of Malaysia, Korea and Hong Kong.

Although Korea, Philippines and Thailand have implemented the inflation targeting after the crisis and the short run interest rate is used as an instrumental tool, we do not observe more effective monetary policy in the post-crisis period in Thailand. The interest rate pass-through from policy rate into lending and deposit rates remains low in these economies. In the other way, both Malaysia and Hong Kong show considerable high pass-through rate into lending and deposit rates.

Malaysia experiences significantly increase in the pass-through rate into deposit and lending rates; While, Hong Kong experiences higher pass-through rate into lending rate in the post-crisis period. Higher pass-through rate indicates that the changes in the policy rate can immediately transform into the retail banking rate. Therefore, the government can effectively influence the economic transmission through the policy rate and the monetary policy is effective in these economies. Also, higher pass-through rate implies higher degree of financial integration and greater degree towards perfect market competition. 
The key determinants of fast transmission of Malaysia can be briefly discussed in few points. These factors are the increase in the efficiency level in banking system, the increase of the alternative financial sources for households and businesses, the emerging of the Islamic financial system, the increase in the financial openness and also the influential of the financing of small and medium sized enterprises (SMEs) Kuang (2008).

Overall, the results indicate that pass-through of policy rate into retail banking rates in Asian is sticky. From the perspective of monetary policy, we hardly find evidence on the effectiveness of monetary policy in Asian as the pass-through rates into deposit and lending rates remain low in many economies and some economies even experience decline in the pass-through rate after the crisis. In these economies, the policy rate has low influences on the deposit and lending rates. This situation implies that the government is not able to effectively control the market rate through the policy rate in bringing the economy to achieve the policy targets. The financial market is imperfect and lacks of financial integration.

\section{References}

Aydin, H, I. (2007). Interest rate pass-through in Turkey. Research and Monetary Policy Department, Working Paper No 07/05. The Central Bank of The Republic of Turkey. [Online] Available: http://www.tcmb.gov.tr/research/discus/WP0705ENG.pdf

Borio, C., \& Fritz, W. (1995). The response of short-term bank lending rates to policy rates: A cross-country perspective. BIS Working Papers no. 27. [Online] Available: www.bis.org/publ/work27.pdf

Cottarelli, C., \& Kourelis, A. (1994). Financial structure, bank lending rates, and the transmission mechanism of monetary policy. IMF Staff Papers, 41(4), 587- 623. http://dx.doi.org/10.2307/3867521

Crespo-Cuaresma, J., Égert, B., \& Reininger, T. (2004). Interest rate pass through in New EU Member States: The Case of the Czech Republic, Hungary and Poland. William Davidson Institute, Working Paper No 671. The University of Michigan Business School. [Online] Available: http://deepblue.lib.umich.edu/bitstream/2027.42/40057/3/wp671.pdf

De Bondt, G. (2002). Retail bank interest rate pass-through: New evidence at the Euro area level. ECB working paper 136. [Online] Available: www.ecb.int/pub/pdf/scpwps/ecbwp136.pdf

De Bondt, G. (2005). Interest rate pass through: Empirical results for the Euro area. German Economic Review, 6 : 37-78. http://dx.doi.org/10.1111/j.1465-6485.2005.00121.x

Donnay, M., \& H. Degryse, (2001). Bank lending rate pass-through and differences in the transmission of a single EMU monetary policy, Discussion Paper, Center for Economic Studies, K.U.Leuven. [Online] Available: www.econ.kuleuven.be/ces/discussionpapers/Dps01/Dps0117.pdf

Espinosa-Vega M.A., \& Rebucci, A. (2003). Retail bank interest rate pass-through and differences in the transmission of a single EMU monetary policy. K.U. Leuven. [Online] Available: www.econ.kuleuven.be/ces/discussionpapers/Dps01/Dps0117.pdf

Fried, J., \& Howitt, P. (1980). Credit rationing and implicit contract theory. Journal of Money, Credit and Banking, 12, 471 - 487. http://dx.doi.org/10.2307/1991722

Grynkiv, I. (2007). Interest rate pass-through in Ukraine. Master thesis, National University Kyiv-Mohyla Academy.

Hofmann, B. (2002). The pass-through of money market rates to business loan rates in the euro area countries. Center for European Integration Studies (ZEI), University of Bonn.

Horvath, C., Kreko, J., \& Naszodi, A. (2004). Interest rate pass-through: the case of Hungary. National Bank of Hungary, Working Paper No $4 . \quad$ Aonline] http://www.univ-orleans.fr/deg/GDRecomofi/Activ/horvath_et_al_es.pdf

Kleimeier, S., \& Sander, H. (2000). Regionalisation versus globalisation in European financial market integration: Evidence from co-integration analyses. Journal of Banking \& Finance, 24(6), 1005-1043. http://dx.doi.org/10.1016/S0378-4266(99)00116-8

Klemperer, P. (1987). Markets with consumer switching costs. The Quarterly Journal of Economics, 102, 375-394. http://dx.doi.org/10.2307/1885068

Kuang, O. S. (2008). The monetary transmission mechanism in Malaysia: Current developments and issues. Bank Negara Malaysia. 
Marotta, G. (2009). Structural breaks in the lending interest rate pass-through and the Euro. Economic Modelling, 26: 191-205. http://dx.doi.org/10.1016/j.econmod.2008.06.01

Mojon, B. (2000). Financial structure and the interest rate channel of ECB monetary.

policy. Working Paper No 40. [Online] Available: http://papers.ssrn.com/sol3/papers.cfm?abstract_id=356001

Moon, H. R., \& Perron, B. (2006). Seemingly unrelated regressions. University of Southern California and Universit'e de Montr'eal.

Mozzami, B. (1999). Lending Rate Stickiness and Monetary Policy Transmission: the Case of Canada and the United States. Applied Financial Economics, Vol. 9, 533-538. http://dx.doi.org/10.1080/096031099331989

Niggle, C.J. (1987). A comment on the markup theory of bank loan rates. Journal of Post Keynesian Economics, 9(4), 629-631.

Rousseas, S. (1985). A markup theory of bank loan rates. Journal of Post Keynesian Economics, Vol. 8(1), 135-144.

Sek, S. K. (2010). The formation of monetary policy in the emerging East-Asian Countries. Economic structures, the source of shocks and the role of exchange rate.VDM Verlag Dr. Müller.

Stiglitz, J.E., \& Weiss A. (1981). Credit rationing in markets with incomplete information, The American Economic Review, 71(3), 393-410.

Toolsema, L., Sturm, J., \& Dehaan, J. (2002). Convergence of pass-through frommoney market to lending rates in EMU countries: New evidence. University of Groningen, Centre for Economic Research, Netherlands. CCSO Working Papers. [Online] Available: http://ccso.eldoc.ub.rug.nl/FILES/root/2002/200206/200206.pdf

Ur Rehman, H. (2009). Interest rate pass-through and banking market Integration in ASEAN: A Cross Country Comparison. Degree of Master thesis, University of Malaya.

Weth, M. (2002). The pass-through from market interest rates to bank lending rates in Germany. Economic Research Centre Of The Deustche Bundesbank, Discussion Paper, 11/02. [Online] Available: http://www.bundesbank.de/download/volkswirtschaft/dkp/2002/200211dkp.pdf

White, Halbert. (1980). A heteroskedasticity-consistent covariance matrix estimator and a direct test for heteroskedasticity. Econometrica, 48 (4), 817-838. http://dx.doi.org/10.2307/1912934

\section{Appendix}

A review of interest rate in Asia

Table 1. Definition of Variables

\begin{tabular}{|c|c|c|c|}
\hline Country & DR & LR & MMR \\
\hline Thailand & Deposit rate & Lending rate & Money market rate \\
\hline Singapore & 3-month bank fixed deposits & Prime lending rate & 3-month interbank rate \\
\hline Philippines & $\begin{array}{c}\text { Deposit rate: } \\
\text { time (61-90 days) }\end{array}$ & Average common lending rate (all maturity) & Money market rate \\
\hline Malaysia & Fixed deposits 3 months & Average lending rate & Interbank overnight money \\
\hline Korea & $\begin{array}{c}\text { Time deposit at DMB: 1 year or } \\
\text { more }\end{array}$ & Lending rate on DMB loans: minimum & Money market rate \\
\hline Indonesia & 3-month deposits & Working capital loans & Money rate \\
\hline Hong Kong & Deposit rate & Lending rate & Money market rate \\
\hline
\end{tabular}

Sources: International Financial Statistics (IFS) 
Table 2. Results of ADF test for pre-crisis period

\begin{tabular}{|c|c|c|}
\hline Variable & DR & $\Delta \mathbf{D R}$ \\
\hline Thailand & -1.592439 & $-8.942869^{* * *}$ \\
Singapore & -2.258673 & $-4.285731^{* * *}$ \\
Philippines & -1.257717 & $-6.045683^{* * *}$ \\
Malaysia & -2.142349 & $-5.995363^{* * *}$ \\
Korea & -1.82567 & $-8.970473^{* * *}$ \\
Indonesia & -1.452862 & $-14.15269^{* * *}$ \\
Hong Kong & -2.330761 & $-5.349958^{* * *}$ \\
\hline Variable & $\mathbf{L R}$ & $\Delta \mathbf{L R}$ \\
\hline Thailand & -1.732204 & $-7.508437^{* * *}$ \\
Singapore & -2.183557 & $-6.378095^{* * *}$ \\
Philippines & -1.55489 & $-12.15^{* * *}$ \\
Malaysia & -1.753925 & $-3.11634^{* *}$ \\
Korea & -1.417509 & $-10.8056^{* * *}$ \\
Indonesia & -1.443652 & $-5.083322^{* * *}$ \\
Hong Kong & -1.457657 & $-7.448755^{* * *}$ \\
\hline Variable & $\mathbf{M M R}$ & $\Delta \mathbf{M M R}$ \\
\hline Thailand & $-3.714919 * * *$ & - \\
Singapore & -1.747751 & $-9.868432^{* * *}$ \\
Philippines & $-8.441082^{* * *}$ & - \\
Malaysia & -1.778494 & $-12.86643^{* * *}$ \\
Korea & $-3.054356 * *$ & - \\
Indonesia & $-3.316938^{* *}$ & $-11.96071^{* * *}$ \\
\hline Hong Kong & -2.106929 & \\
\hline
\end{tabular}

Notes: $* * * \quad=1 \%$ critical value, $* * \quad=5 \%$ critical value, ${ }^{*} \quad=10 \%$ critical value,

$\mathrm{DR}=$ deposit rate, $\mathrm{LR}=$ lending rate, $\mathrm{MMR}=$ money market rate, $\Delta \mathrm{DR} \quad=$ first differencing operator of deposit rate, $\Delta \mathrm{LR}=$ first differencing operator of lending rate, $\Delta \mathrm{MMR}=$ first differencing operator of money market rate.

Table 3. Results of ADF test for post-crisis period

\begin{tabular}{|c|c|c|}
\hline Variable & DR & $\Delta \mathbf{D R}$ \\
\hline Thailand & -2.22084 & $-5.60108^{* * *}$ \\
Singapore & -1.53647 & $-9.076^{* * *}$ \\
Philippines & -1.4384 & $-17.1682^{* * *}$ \\
Malaysia & -1.56949 & $-11.7262^{* * *}$ \\
Korea & -2.02698 & $-9.41816^{* * *}$ \\
Indonesia & -2.20712 & $-10.6601^{* * *}$ \\
Hong Kong & -1.69586 & $-6.92554^{* * *}$ \\
\hline Variable & $\mathbf{L R}$ & $\Delta \mathbf{L R}$ \\
\hline Thailand & $-2.88549 * *$ & - \\
Singapore & -2.05785 & $-11.865^{* * *}$ \\
Philippines & $-3.0547 * *$ & - \\
Malaysia & -1.3356 & $-4.75021^{* * *}$ \\
Korea & $-3.00295^{* *}$ & - \\
Indonesia & $-4.92429 * * *$ & - \\
Hong Kong & -1.85557 & $-4.07956^{* * *}$ \\
\hline Variable & $\mathbf{M M R}$ & $\Delta \mathbf{M M R}$ \\
\hline Thailand & -1.81531 & $-6.39305^{* * *}$ \\
Singapore & -1.38672 & $-3.94517^{* * *}$ \\
Philippines & -2.23578 & $-3.65137^{* * *}$ \\
Malaysia & $-4.22013^{* * *}$ & - \\
Korea & -1.91923 & $-4.6522^{* * *}$ \\
Indonesia & $-3.3049^{* *}$ & - \\
Hong Kong & -1.44234 & $-2.94808^{* *}$ \\
\hline
\end{tabular}

Notes: $* * *$ 
$\mathrm{DR}=$ deposit rate, $\mathrm{LR}=$ lending rate, $\quad \mathrm{MMR}=$ money market rate, $\Delta \mathrm{DR}=$ first differencing operator of deposit rate, $\Delta \mathrm{LR}=$ first differencing operator of lending rate, $\Delta \mathrm{MMR}=$ first differencing operator of money market rate.

Table 4. Results of LM test for pre- and post-crisis period

\begin{tabular}{|c|c|c|c|}
\hline Period & Countries & $\lambda_{L M}=T \sum_{i=2}^{M} \sum_{j=1}^{i-1} r_{i j}^{2}$ & Decision \\
\hline Pre-crisis & $\begin{array}{l}\text { Thailand } \\
\text { Singapore } \\
\text { Philippines } \\
\text { Malaysia } \\
\text { Korea } \\
\text { Indonesia } \\
\text { Hong Kong }\end{array}$ & $\begin{array}{l}18.99546 \\
76.81518 \\
14.11680 \\
0.000000 \\
49.39248 \\
0.163200 \\
0.000000\end{array}$ & $\begin{array}{l}\lambda_{L M}>\chi^{2}, \text { use GLS } \\
\lambda_{L M}>\chi^{2}, \text { use GLS } \\
\lambda_{L M}>\chi^{2}, \text { use GLS } \\
\lambda_{L M}<\chi^{2}, \text { use GLS or OLS } \\
\lambda_{L M}>\chi^{2}, \text { use GLS } \\
\lambda_{L M}<\chi^{2}, \text { use GLS or OLS } \\
\lambda_{L M}<\chi^{2}, \text { use GLS or OLS }\end{array}$ \\
\hline Post-Crisis & $\begin{array}{l}\text { Thailand } \\
\text { Singapore } \\
\text { Philippines } \\
\text { Malaysia } \\
\text { Korea } \\
\text { Indonesia } \\
\text { Hong Kong }\end{array}$ & $\begin{array}{c}37.21003 \\
51.15396 \\
6.9784 \\
9.02759 \\
41.78889 \\
17.55897 \\
39.5824\end{array}$ & $\begin{array}{l}\lambda_{L M}>\chi^{2}, \text { use GLS } \\
\lambda_{L M}>\chi^{2}, \text { use GLS } \\
\lambda_{L M}>\chi^{2}, \text { use GLS } \\
\lambda_{L M}>\chi^{2}, \text { use GLS } \\
\lambda_{L M}>\chi^{2}, \text { use GLS } \\
\lambda_{L M}>\chi^{2}, \text { use GLS } \\
\lambda_{L M}>\chi^{2}, \text { use GLS }\end{array}$ \\
\hline
\end{tabular}

Notes: $\quad \chi_{\alpha, M(M-1) / 2}^{2}=\chi_{0.05,2(2-1) / 2}^{2}=\chi_{0.05,1}^{2}=3.841$

Table 5. Pass-through into deposit rate

\begin{tabular}{|c|c|c|c|c|c|}
\hline & Short run & Long run & R-Squared & $\begin{array}{l}\text { Determinant } \\
\text { Covariance }\end{array}$ & Residual \\
\hline \multicolumn{6}{|l|}{ Thailand } \\
\hline pre-crisis & 0.058456 & 0.054819 & 0.159352 & 0.023254 & \\
\hline post-crisis & 0.001732 & 0.001886 & 0.147333 & 0.000767 & \\
\hline \multicolumn{6}{|l|}{ Singapore } \\
\hline pre-crisis & 0.164041 & 0.178167 & 0.182298 & 4.44E-05 & \\
\hline post-crisis & 0.091017 & 0.092996 & 0.157743 & $5.00 \mathrm{E}-07$ & \\
\hline \multicolumn{6}{|l|}{ Philippines } \\
\hline pre-crisis & 0.076204 & 0.066308 & 0.070102 & 1.151666 & \\
\hline post-crisis & 0.014159 & 0.012337 & 0.313848 & 0.293256 & \\
\hline \multicolumn{6}{|l|}{ Malaysia } \\
\hline pre-crisis & 0.170653 & 0.292355 & 0.335411 & 0.000376 & \\
\hline post-crisis & 0.740218 & 0.689479 & 0.741931 & $2.10 \mathrm{E}-05$ & \\
\hline \multicolumn{6}{|l|}{ Korea } \\
\hline pre-crisis & 0.004022 & 0.004543 & 0.033344 & 0.005727 & \\
\hline post-crisis & 0.002899 & 0.004322 & 0.410314 & 0.000337 & \\
\hline \multicolumn{6}{|l|}{ Indonesia } \\
\hline pre-crisis & 0.139113 & 0.099917 & 0.194008 & 0.189189 & \\
\hline post-crisis & -0.019283 & -0.080119 & 0.730918 & 0.018179 & \\
\hline \multicolumn{6}{|l|}{ China(HK) } \\
\hline pre-crisis & 0.693119 & 0.842740 & 0.310952 & 0.002208 & \\
\hline post-crisis & 0.282799 & 0.377415 & 0.433255 & 0.000407 & \\
\hline
\end{tabular}


Table 6. Pass-through into lending rate

\begin{tabular}{|c|c|c|c|c|c|}
\hline & Short run & Long run & R-Squared & $\begin{array}{l}\text { Determinant } \\
\text { Covariance }\end{array}$ & Residual \\
\hline \multicolumn{6}{|l|}{ Thailand } \\
\hline pre-crisis & 0.035289 & 0.041326 & 0.159352 & 0.023254 & \\
\hline post-crisis & 0.008275 & 0.010862 & 0.18466 & 0.000767 & \\
\hline \multicolumn{6}{|l|}{ Singapore } \\
\hline pre-crisis & 0.130558 & 0.164684 & 0.255810 & 4.44E-05 & \\
\hline post-crisis & 0.031317 & 0.039854 & 0.210929 & $5.00 \mathrm{E}-07$ & \\
\hline \multicolumn{6}{|l|}{ Philippines } \\
\hline pre-crisis & 0.160404 & 0.119368 & 0.190445 & 1.151666 & \\
\hline post-crisis & 0.011385 & 0.007906 & 0.207106 & 0.293256 & \\
\hline \multicolumn{6}{|l|}{ Malaysia } \\
\hline pre-crisis & 0.058462 & 0.065742 & 0.052147 & 0.000376 & \\
\hline post-crisis & 0.470218 & 0.480312 & 0.552604 & $2.10 \mathrm{E}-05$ & \\
\hline \multicolumn{6}{|l|}{ Korea } \\
\hline pre-crisis & -0.013795 & -0.01279 & 0.012133 & 0.005727 & \\
\hline post-crisis & 0.004724 & 0.006723 & 0.538609 & 0.000337 & \\
\hline \multicolumn{6}{|l|}{ Indonesia } \\
\hline pre-crisis & 0.102618 & 0.083417 & 0.285147 & 0.189189 & \\
\hline post-crisis & -0.011451 & -0.045879 & 0.675487 & 0.018179 & \\
\hline \multicolumn{6}{|l|}{ China(HK) } \\
\hline pre-crisis & 0.063217 & 0.063124 & 0.252777 & 0.002208 & \\
\hline post-crisis & 0.189380 & 0.270825 & 0.343558 & 0.000407 & \\
\hline
\end{tabular}

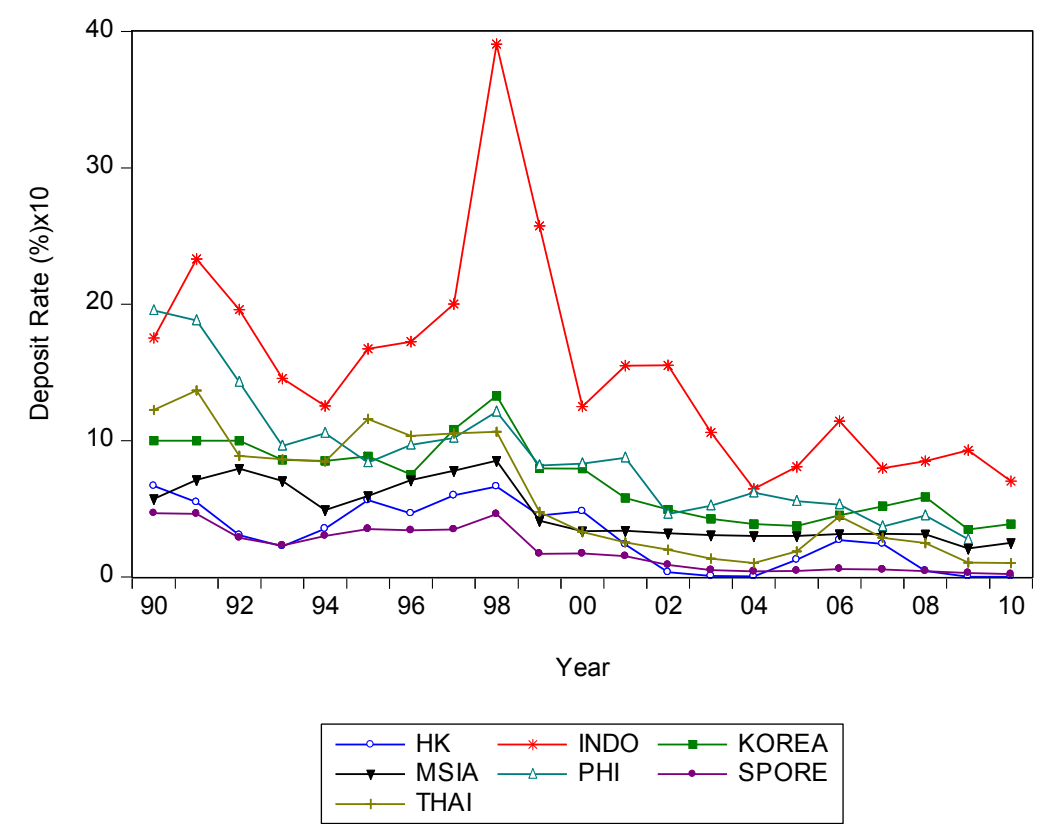

Figure 1. Graph of Deposit Rate (DR) Comparison

Sources: International Financial Statistics (IFS) 


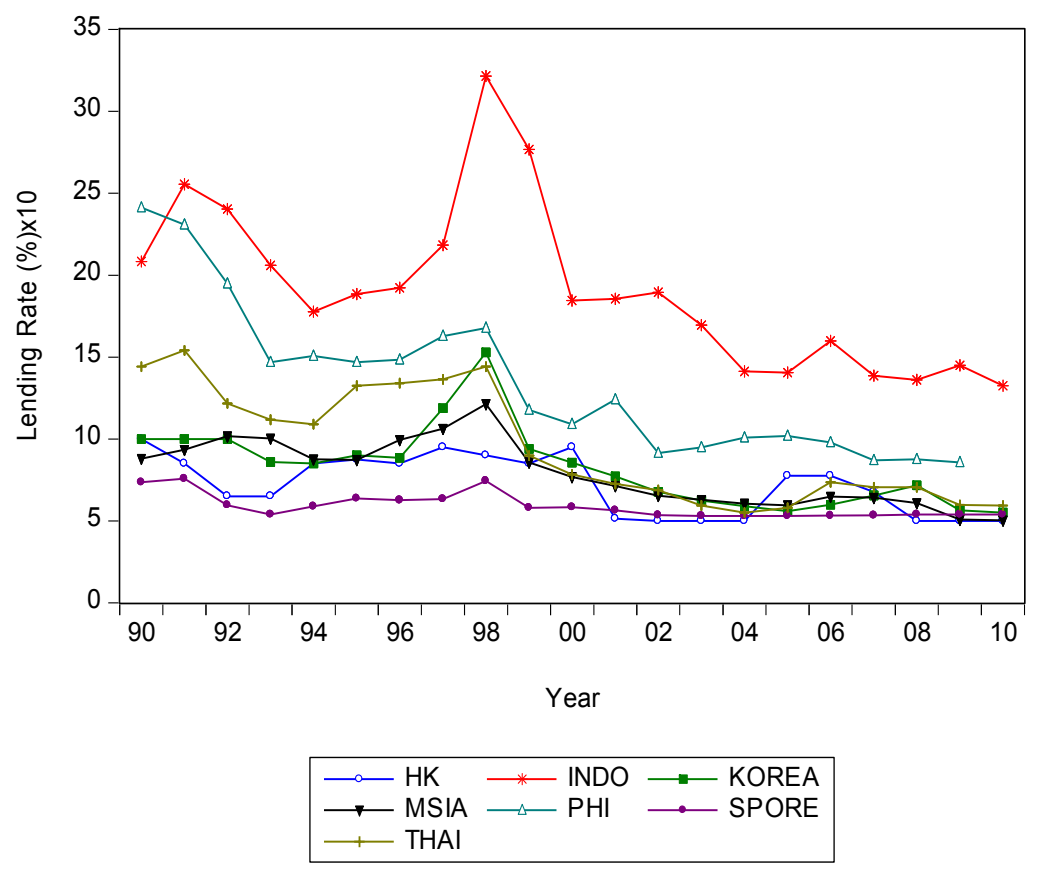

Figure 2. Graph of Lending Rate (LR) Comparison

Sources: International Financial Statistics (IFS)

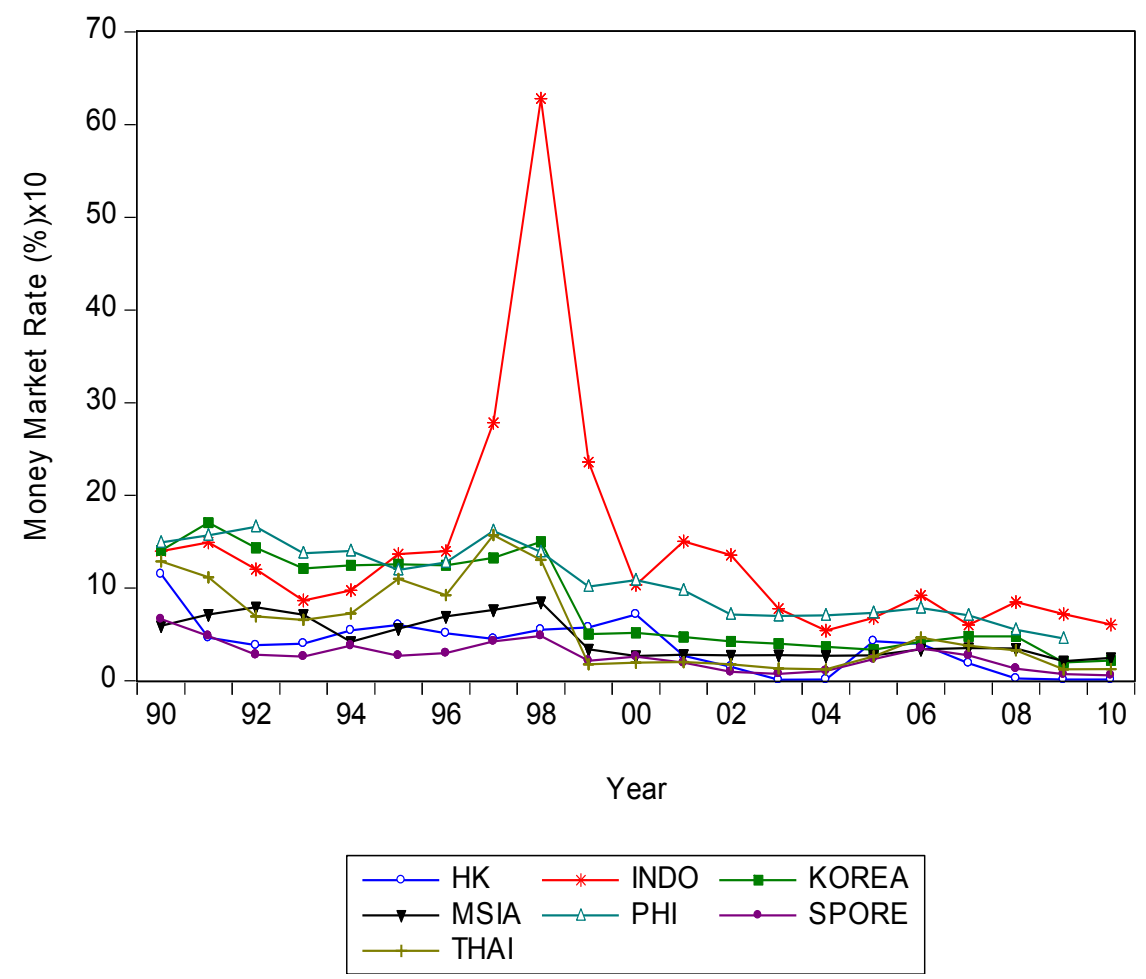

Figure 3. Graph of Money Market Rate (MMR) Comparison

Sources: International Financial Statistics (IFS) 


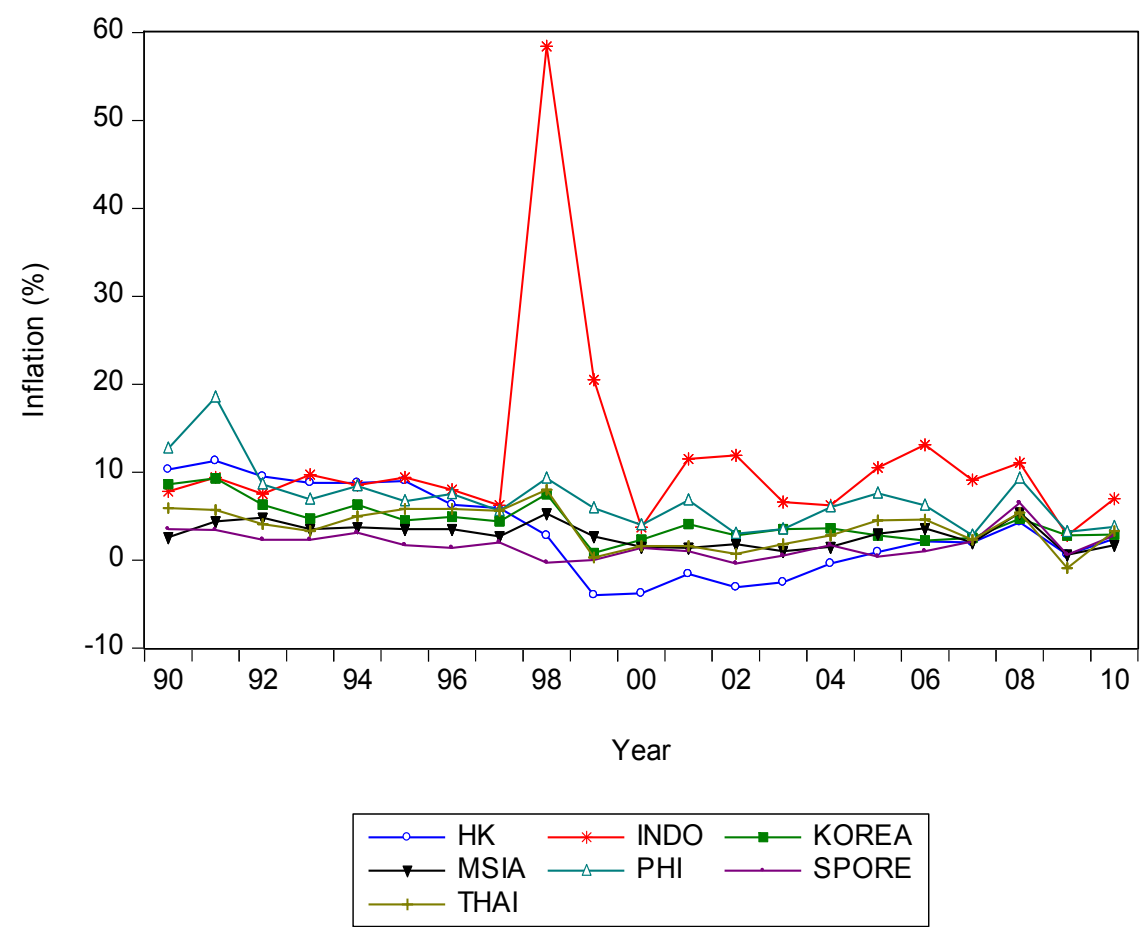

Figure 4. Graph of Inflation Rate (\%)

Sources: International Financial Statistics (IFS) 